\title{
Fantasmata- Between Movements: Dance Education and Contemporary Demands
}

\section{Marta Reolon $\mathbf{V}^{*}$ \\ Federal University of Rio Grande do Sul, Brazil}

*Corresponding author: Vera Marta Reolon, Federal University of Rio Grande do Sul, Carlos Bianchini, 1149/04, Caxias do Sul, RS, Brazil, Tel: 555435384041; Email: verareolon@terra. com.br

\section{Perspective}

Volume 4 Issue 4

Received Date: December 06, 2021

Published Date: December 28, 2021

DOI: $10.23880 /$ phij-16000211

\section{Abstract}

In order to arrive at a concept (as a goal) of global health, we think of a search for Care of Self, through art (of dance, but not only), seeking a quality education, uniting the necessary aesthetics with ethics (more than necessary!). The interdisciplinary between the different knowledge's (psychoanalysis, philosophy, education, art, etc.), the studies of the movement, of the times can give us great notions of health and thus, we arrive at the so desired care of itself, advocated by Foucault.

Keywords: Dance; Education; Academy (University); Art; Interdisciplinarity

Feeling alive, human wellspring at the touch of another human being who is not afraid to explore the rough depths

-JS Martins

I await the day when I will be a judge of myself and I will know if I have virtue on my lips and in my heart (SENECA, letter 26, apud FOUCAULT, 1997, p.134).

His description is artistically modulated and balanced. This is called STYLE. This is art. That's the only thing that matters in books. (NABOKOV over FLAUBERT).

The essence of dance is not movement, but TIME. "Ghosts" stand between the movement and its cessation. It is this nonmovement that is movement that is essential to dance. That which makes it untouchable, what it is and is not (being!), the fullness of being and the emptiness of being, potency and impotence, act and non-act. FANTASMATA is the term used to determine this «between-acts», the between one movement and another in/of the dance. «Ghosts» not in the literal sense of «phantasmagoric», but empty movements, which evidence an act/time between -acts...
What is it? What kind of emptiness is it? Is it empty? What time are you talking about? Clock time? The scheduled time, the measured time? If not, what kind of weather is it? What is the essence of the song? Is music essential to dance? Is dance an art? - There seems to be no doubt about this basic premise, but why do schools not consider dance as part of a great educational process, aimed at broad education? How to implement a new formulation in dance at the Academy (Plato's - synonymous with University, nowadays) aimed at professional teachers, graduates marked with the 


\section{Philosophy International Journal}

art of dance, but the art of TEACHING DANCE?

What would it be like to teach dance and learn more about the ART of dance?

How to see dance - art and deepen its concepts and elements?

From LDB 9694/96 onwards, Art Education classes should bring art-language-dance to their curricula, students and teachers as agents of their own practices, through Interdisciplinary Projects via Theme Generator.

Is this enough to see dance as an important art in learning processes? I say that it, dance, is "inserted" in schools via a generative theme and, specifically, as LAW, so that it is absorbed by the school population as ART? How required art?

Dance as a transversal theme and not as a field of fundamental importance in the development of higher cognitive processes of movement, balance, technique, resourcefulness, posture, body work - not just in the contemporary movements of a search for perfect bodies, but in a search for global health, similarly to the Greek world in which ethics in living was not disconnected from aesthetics, bodily health care, good living, art in and living.

Having a Dance teacher, with a Dance Degree (which is very different, being a dance teacher and a dance teacher!) who has interdisciplinary knowledge of the various subjectivities and needs to study approaches to these subjectivities is essential to achieve objectives that we all criticize when we talk about the art of dance, the art of dance as a need for knowledge in art, in aesthetics, from school onwards, not only as a mere help in different artistic education, but as the development of superior skills, including assessments cultural and about culture, of the development of a so-called broad culture, which does not stop at fragments, but moves towards EDUCATION, in its broadest sense.

Addressing and expanding the notions of SELF CARE, as self-knowledge, as a search for a broad culture, education, health, self-art, seems to be essential to achieve what the Greeks believed to be ETHICS, the center of ethos existential.

Implementing these ideas in dance learning, in the training of undergraduates engaged in a new look at life, art, living with art, seems to me essential for the relevance of dance at school to take on an air of true interdisciplinarity, perhaps transdisciplinarity. Talking about the difference of both concepts also seems important for the Academy of today!.

The studies of movement, movement and its cessation (which is also movement) are intimately linked to all doing in dance, when they are not dance itself. So say all the great choreographers in modern and contemporary dance, Isadora Duncan, Marta Graham, Merce Cunninghan, Pina Bausch, among others. But not only those of Modern and Contemporary Dance, but all the dancers.

Movement studies require an "observer" linked to multiple knowledge, which implies knowledge in physics, mathematics, body, biology, unconscious, history, sociology, philosophy, psychoanalysis, knowledge that is not always involved in the same fragment of school, in a same fragment and segment within the academy. It includes passages, paths that have been and should be traced by an observer interested in inter and transdisciplinary movements.

It is relevant and justified to advance towards new studies in dance, an ancient art, but still involved in veils of ignorance regarding its presuppositions.

Psychoanalysis, as an interpretive theory of reality, serves to analyze phenomena, in the individual field, through the manifestations of the unconscious, present in the language of different subjects, in jokes, in the interpretation of dreams, etc. It can, however, interpret social phenomena by analyzing the manifestations of society, organizations and institutions, and social groups. Combining philosophy, essential for its development since the beginning, psychoanalysis, in addition to performing interpretations, reflects on facts, using the theories of great thinkers.

Departing, therefore, from Derrida's deconstructive writing, the psychoanalytic discourse is what can account for contemporary issues: "If there is a discourse that could, nowadays, claim the cause of psychic cruelty as its own subject, this is which has been called, for about a century now, psychoanalysis" (p. 8-9) [1].

I launch a hypothesis that it is educational processes that can provide an answer to major contemporary questions. Can education address these issues? Can she exempt herself from that? How to educate without making this passage?

Never, in any other time in our history, has man been alone in a crowd. The ideals that supported it have fallen, happiness no longer depends on the harmony of social bonds, but on objects acquired and offered incessantly by the media and general marketing instruments. There is an offer of full enjoyment. The foreclosure of the Law of life is paid with tithes. The subject is transformed, through his murder, into a submissive object of the Other's enjoyment. There's nothing more psychotic than that. In the diseases of modernity, anorexia, bulimia, drug addiction, what you have are shadows that the world of lights does not illuminate. Modernity offers us a world illuminated by billboards full of offers, neon lights, 
which do not illuminate the necessary search for man and himself. Our I, who I am, where I am going, what I want (?), there is no answer. The offer we have is the death drive at all times. The market demands offers where the consumer needs and cannot live without the merchandise. This is the paradigm model that encompasses drug addictions; it is their cause and consequence. What comes before, a world that facilitates drug addictions, or do they originate the world? We don't know, we should think about it. Modern diseases refer to the subject's death, a second death that comes before the first (interruption of life), as this second is the subject's death in the Symbolic.

Michel Foucault, in his seminars on the Government of Self and Others and on the Hermeneutics of the Subject, addresses and discusses self-care as a broad issue of a search for health that meets self-knowledge, with knowledge of your body, with the knowledge of your needs, your desires, with a view to a broad search for happiness, no longer as a utopian, subjective, unattainable search (perhaps too ideal!) but, through this self-knowledge, a possible, palpable, experienceable happiness: "Philosophy is assimilated to care for the soul (the term is precisely medical: hugiainein ), and this care is a task that must be followed throughout life" (p. 120) [2].

Hermeneutics of the self => epimelea heautou (Greek) cura sui (Latin) - principle of taking care of oneself $=>$ taking care of oneself $=>$ knowing oneself $=>$ obscured by the glow of the Gnôthi seauton (p. 119) [2].

Psychoanalysis, especially Lacanian, when it addresses the Logic of the Phantom, an important concept that differentiates between fantasy - structurally linked to neurosis - as a symptom, or rather, presentation, form of manifestation of the symptom of neurosis, different from form of manifestation of perversion, even present in the maxim "where the neurotic fantasizes, the pervert does"; and ghost ("fantôme"), mark, identification in the subjectivity of each subject, to the Other's imaginary ("your" Mother!), which from the Other's imaginary remains as a Real mark in the subjective structure of the speaking being.

How, after that, will we define reality to what I called the ready to carry the ghost a little while ago, that is, what your picture does and we will see then that reality, all human reality, is nothing more than a montage of the Symbolic and the Imaginary - that the desire, at the center of this apparatus, of this framework that we call reality, is also, to speak properly, what happens, as I have always articulated it, what matters to distinguish from human reality and which is to speak properly of the Real, which is never but interviewed; I interview when the mask, which is that of the ghost, falters. Namely, the same thing as what Spinoza seized, when he said: "desire is the essence of man" (p.19) [3].

For what the work of art has to do with socio-cultural elements?: "The work of art contains historical and social elements that aesthetics has the task of explaining. The work not only "judges" history and society in its own way, but it is itself a candidate for the appreciation and evaluation of the public" (p.374) [4].

According to Walter Benjamim, the aura is a vehicle for deceleration that seems to be diluted or incompatible with the experiences of "modernity's shock" and with capitalism's dreams of immediate consumption. Art, for Benjamim, is through his "Aura", what defines it as art, what makes the difference between a common object and what establishes it as a work of art [5].

According to Deleuze, the event is not what happens (accident), it is IN what happens, the pure expression that gives us a signal and waits for us. The event does not show how meaning is formed, but how it derives from a state of affairs. The event is the sense itself, the sense produced. The event installs itself directly in time. For Deleuze, nonsense is not meaningless, but where is the total of being, its potency, that is, where SENSE is MAXIMUM [6].

Stop $=>$ possibility of an act that criticizes the action. Act stopped, act of resistance.

Agamben makes relationships between time and image. Agamben discusses in his text the question of time and the Fantasmata in dance.

Aristotle claims about the dignity of dance $=>$ Dance is both intellectual and practical. Art made up of six elements: measure, memory, agility, manner, terrain measure and "fantasmata". "Only beings who perceive time remember, and with the same faculty of imagination..." Domenico De Piacenza takes up the concept of movement in dance from Aristotle [7]:

\section{“ danzare per fantasmata " => many things that cannot be said.}

Fantasmata $=>$ body readiness - improvised impediment - delay between two movements. From him emerges the image like Medusass hair, which moves and which we cannot look at. $\downarrow$

Hence the internal tension between measurement and memory in the complete series of choreography. 


\section{Philosophy International Journal}

This non-movement that is movement is what seems to me to be essential to dance. That which makes it untouchable.

It is the ghost that is reached by touching essences: "Dance is this art that, when touching the essence of movement, ceases to have meaning and is only recovered in the stopped act, in the STOP" (p. 96-97) [8].

Spatio-temporal relationships contained in traditional dances and artistic productions are directly related to cultural plurality, as they express and communicate concepts and experiences from different times and geographic spaces.

Who can dance? Who can dance what? What are the different concepts of the body?

A teacher can emphasize dancing bodies and dancing bodies.

Learning dance means incorporating values and attitudes. As dance can (and can!), change a whole state of violence that exists in the social, through experiences and learning of and in art [9].

BEING A DANCE TEACHER IS MORE THAN BEING A DANCER, IT'S BEING SOMEONE WHO UNDERSTANDS THE MOVEMENT IN DANCE! AND TRANSMITS IT.

\section{References}

1. Derrida J (2001) Estados-da-alma da psicanálise. São Paulo: Escuta.

2. Foucault M (1997) Resumo dos Cursos do College de France. Rio de Janeiro, Zahar.

3. Lacan J (2008) O seminário: a lógica do fantasma (19661967). Recife: Centro de estudos freudianos do Recife.

4. Jimenez M (1999) O que é Estética?. São Leopoldo:Unisinos.

5. Benjamin W (2009) Estética Y Política. Buenos Aires: Las Cuarenta.

6. Deleuze G, Guattari F (1966) O Anti-Édipo: Capitalismo e Esquizofrenia. Lisboa: Assírio e Alvim.

7. Aristóteles (1985) Ética a Nicômacos. $3^{\text {rd }}$ (Edn.), Brasília: Editora da Universidade de Brasília.

8. Tiburi M, Rocha T (2012) Diálogo: Dança. São Paulo: SENAC.

9. Reolon VM (2008) Mulheres para um homem... para O Homem, A Mulher. Porto Alegre: EDIPUCRS. 